\title{
Impact of ammonium nitrate and Microbion UNC bacterial fertilizer on dry matter accumulation of ryegrass (Lolium perenne $\mathrm{L}$.)
}

\author{
Andrea Balla Kovács - Anita Jakab \\ Department of Agricultural Chemistry and Soil Science, \\ University of Debrecen, \\ 4032 Debrecen Böszörményi út 138. Hungary, \\ E-mail:kovacsa@agr.unideb.hu
}

Keywords: ammonium-nitrate, bacterial fertilizer, dry matter accumulation, ryegrass

\begin{abstract}
Pot experiment was performed to investigate the effects of increasing $\mathrm{NH}_{4} \mathrm{NO}_{3}$ doses with or without Microbion UNC bacterial fertilizer application on dry matter production of ryegrass (Lolium perenne L.). Experiment was set up on calcareous chernozem soil of DebrecenLátókép and on humus sandy soil of Örbottyán. The bi-factorial trials were arranged in a randomized complete block design with four replications. Grass was cut three times. Dry matter production was determined and the sum of biomass of cuts was calculated as cumulated dry weights. Analysis of variance was carried out on the data in order to provide a statistical comparison between the treatment means. The least significant difference $\left(\mathrm{LSD}_{5 \%}\right)$ test was used to detect differences between means. On the basis of our results it can be concluded, that the dry weights of ryegrass cultivated on chernozem soil were higher than on sandy soil. With increasing nitrogen supply the dry matter production of grass significantly increased in both types of soils. In case of sandy soil the increasing effect was more expressed, but dry weights of this soil never reached the appropriate values of chernozem soil. Application of Microbion UNC had positive effect on dry matter production of ryegrass grown on both two types of soils but the effect was more expressed on chernozem soil. Finally it can be concluded that the increasing effect of $\mathrm{NH}_{4} \mathrm{NO}_{3}$ on biomass weights was more expressed in both types of soils, the biofertilizer application also increased the dry weights of plant in a small degree.
\end{abstract}

\section{INTRODUCTION}

One of the most important nutrient required for plant growth is nitrogen. Nitrogen is found naturally in the atmosphere and in the soil (Stevenson \& Cole, 1999). The nitrogen $\left(\mathrm{N}_{2}\right)$ in the atmosphere can not be utilized by plants because plants take up nitrogen as ammonium $\left(\mathrm{NH}_{4}{ }^{+}\right)$and nitrate $\left(\mathrm{NO}_{3}{ }^{-}\right)$from soil. These nitrogen forms can be added to the soil as various nitrogen fertilizers (Black, 1968). The use of nitrogen fertilizers is a standard practice in plant production system, but extensive or one-sided use of chemical fertilizers may cause environmental pollution, ecological damage and increased production costs (Jordan and Weller, 1996; Kádár et al. 2007; Ghost and Bhat, 1998).

For reducing chemical fertilizers application an alternative method must be developed. For this reason, environmental friendly products such as bacterial fertilizers should be used (Bambal et al., 1998; Panwar et al., 2000).

Bacterial fertilizers are products containing different types of microorganisms (Hegde et al., 1999; Vessey, 2003; Vance, 1997), for example nitrogen fixing, phosphate solubilizing bacteria and cellulolytic microorganisms. They may promote plant growth and health by various means such as nodulation and nitrogen fixation, mineralization of nutritional elements (Malboobi et al., 2009), and they may augment the availability of nutrients to the plants. Nevertheless the performance of biofertilizers is severely influenced by both biotic and abiotic environmental conditions also.

In the literature, there are some reports which are dealing with nitrogen fertilization (Sipos \& Vágó, 2007), but little attention has been paid to study the effects of bacterial fertilizers and the effects of combined application of $\mathrm{N}$ and biofertilizers (Kincses et al., 2008; Kátai et al., 2008).

The objective of this research was to evaluate the impacts of increasing doses of $\mathrm{NH}_{4} \mathrm{NO}_{3}$ with or without Microbion UNC biofertilizer application on dry weight accumulation of ryegrass cultivated on chernozem and sandy soils.

\section{MATERIALS AND METHODS}

Pot experiment was performed in 2008 in the greenhouse of the Department of Agricultural Chemistry and Soil Sience, Centre for Agricultural and Applied Economic Sciences, University of Debrecen. The experiment was set up on calcareous chernozem soil of Debrecen-Látókép (1) and on humus sandy soil of Örbottyán (2). The basic properties of soils are included in Table 1 . 
Some physical and chemical features of experimental soils

\begin{tabular}{|c|c|c|c|c|c|}
\hline Soil no. & $\mathrm{Hu} \%$ & $\mathrm{~K}_{\mathrm{A}}$ & $\mathrm{pH}_{\mathrm{KCl}}$ & $\mathrm{AL}-\mathrm{P}_{2} \mathrm{O}\left(\mathrm{mg} \mathrm{kg}^{-1}\right)$ & $\mathrm{AL}-\mathrm{K}_{2} \mathrm{O}\left(\mathrm{mg} \mathrm{kg}^{-1}\right)$ \\
\hline 1. & 3.02 & 35 & 6.43 & 352 & 1254 \\
\hline 2. & 0.75 & 26 & 7.20 & 106.3 & 65.1 \\
\hline
\end{tabular}

$\mathrm{K}_{\mathrm{A}}$ : Plasticity index according to Arany

Six-six $\mathrm{kg}$ soil (chernozem soil and sandy soil) were weighed into the pots. The bi-factorial trials were arranged in a randomized complete block design with four replications, applying three levels of $\mathrm{NH}_{4} \mathrm{NO}_{3}$ with or without application of biofertilizer Microbion UNC (Table 2.).

Table 2.

Treatments and nominations of the experiment

\begin{tabular}{|c|c|c|}
\hline Treatment codes & $\begin{array}{c}\mathrm{N} \\
\left(\mathrm{g} \mathrm{pot}^{-1}\right)\end{array}$ & $\begin{array}{c}\text { Microbion UNC } \\
\left(\mathrm{g} \mathrm{pot}^{-1}\right)\end{array}$ \\
\hline $\mathrm{N}_{0}$ (control) & 0 & 0 \\
\hline $\mathrm{N}_{1}$ & 0.60 & 0 \\
\hline $\mathrm{N}_{2}$ & 1.20 & 0 \\
\hline $\mathrm{N}_{3}$ & 1.80 & 0 \\
\hline $\mathrm{N}_{0}+$ Microbion UNC & 0 & 0.10 \\
\hline $\mathrm{N}_{1}+$ Microbion UNC & 0.60 & 0.10 \\
\hline $\mathrm{N}_{2}+$ Microbion UNC & 1.20 & 0.10 \\
\hline $\mathrm{N}_{3}+$ Microbion UNC & 1.80 & 0.10 \\
\hline
\end{tabular}

Nitrogen was applied as $\mathrm{NH}_{4} \mathrm{NO}_{3}, \mathrm{P}$ and $\mathrm{K}$ as $\mathrm{KH}_{2} \mathrm{PO}_{4}$ and $\mathrm{K}_{2} \mathrm{SO}_{4}$ solutions. $\mathrm{P}$ and $\mathrm{K}$ doses were identical in all pots $\left(0.6 \mathrm{~g} \mathrm{P}_{2} \mathrm{O}_{5}\right.$ pot $^{-1}$ and $\left.0.6 \mathrm{~g} \mathrm{~K}_{2} \mathrm{O} \mathrm{pot}^{-1}\right)$.

The applied biofertilizer was Microbion UNC, which contains various microorganisms, Azotobacter vinelandii-B 1795, Bacillus megaterium-B1091, Clostridium pasteurianum, Azospirillum sp., Bacillus subtilis, Rhodobacter sp., Lactobacillus sp., Trichoderma reseei, Saccharomyces cerevisiae, Streptomyces sp., agents, vitamins synthetized by microorganisms, GM-8 corncob milling product and dried brewer's yeast.

Solution of nutrients and also biofertilizer were mixed up thoroughly with the soil to ensure homogeneous distribution.

The experimental plant species was ryegrass (Lolium perenne L.). $2 \mathrm{~g}$ seed/pot of ryegrass were sown into the soil per pot on 16 April 2008.

Ion exchanged water was added to all pots to keep the soil at constant moisture $(60 \%$ of the water-holding capacity) using daily weighing. At high vegetative masses of plants, and also on hot days, the irrigation was performed twice a day (in the morning and in the afternoon) to avoid wilting.

Ryegrass was cut three times. First, the $2^{\text {nd }}$ and the $3^{\text {rd }}$ cuts of plants were accomplished on 19 May, on 17 June, and on 15 July, respectively. The grass was first air-dried and than dried at $60 \mathrm{C}^{\circ}$ until reaching constant mass. The biomass production of cuts was determined by weighing. The sum of biomass weights of $1^{\text {st }}, 2^{\text {nd }}$ and $3^{\text {rd }}$ cuts per pots also was calculated as cumulated dry weight.

Analysis of variance was carried out on the data in order to provide a statistical comparison between the treatment means. The least significant difference (LSD $5 \%$ ) test was used to detect differences between means.

\section{RESULTS AND DISCUSSION}

The effects of increasing $\mathrm{NH}_{4} \mathrm{NO}_{3}$ doses with or without biofertilizer application on biomass production of ryegrass in $1^{\text {st }}, 2^{\text {nd }}$ and $3^{\text {rd }}$ cuts are summarized in Table 3 . The results of statistical analysis are presented in Table 4. 


\begin{tabular}{|c|c|c|c|c|c|c|}
\hline \multirow[b]{3}{*}{ N supply } & \multicolumn{6}{|c|}{ sandy soil } \\
\hline & \multicolumn{3}{|c|}{$\mathrm{NH}_{4} \mathrm{NO}_{3}$} & \multicolumn{3}{|c|}{$\mathrm{NH}_{4} \mathrm{NO}_{3}+$ Microbion $\mathrm{UNC}$} \\
\hline & $\begin{array}{c}1^{s t} c u t \\
\left(g p o t^{-1}\right)\end{array}$ & $\begin{array}{l}2^{\text {nd }} \text { cut } \\
\left(g \text { pot }^{-1}\right)\end{array}$ & $\begin{array}{c}3^{r d} \text { cut } \\
\left.\left(g_{p o t}\right)^{-1}\right)\end{array}$ & $\begin{array}{c}1^{s t} \text { cut } \\
\left(g p o t^{-1}\right)\end{array}$ & $\begin{array}{c}2^{\text {nd }} \mathrm{cut} \\
\left(\mathrm{g} \mathrm{pot}^{-1}\right)\end{array}$ & $\begin{array}{c}3^{r d} c u t \\
\left(g p o t^{-1}\right)\end{array}$ \\
\hline$N_{0}$ & 1.60 & 1.17 & 1.54 & 1.63 & 0.83 & 2.35 \\
\hline$N_{l}$ & 8.60 & 5.17 & 3.76 & 9.55 & 5.56 & 4.34 \\
\hline $\mathrm{N}_{2}$ & 8.65 & 11.23 & 6.48 & 9.60 & 12.58 & 4.96 \\
\hline \multirow[t]{2}{*}{$N_{3}$} & 9.52 & 14.83 & 7.47 & 9.69 & 14.17 & 7.26 \\
\hline & \multicolumn{6}{|c|}{ chernozem soil } \\
\hline$N_{0}$ & 5.57 & 3.13 & 4.81 & 5.93 & 3.65 & 5.05 \\
\hline$N_{l}$ & 10.73 & 7.45 & 4.38 & 10.53 & 8.75 & 5.08 \\
\hline $\mathrm{N}_{2}$ & 11.57 & 15.47 & 7.22 & 11.93 & 16.35 & 6.84 \\
\hline$N_{3}$ & 11.40 & 20.01 & 12.46 & 12.85 & 20.91 & 12.47 \\
\hline
\end{tabular}

The effects of treatments on dry matter production of $1^{\text {st }}, 2^{\text {nd }}$, and $3^{\text {rd }}$ cuts of ryegrass (table of variance)

\begin{tabular}{|c|c|c|c|c|}
\hline & sandy soil & chernozem soil & sandy soil \\
\hline effects & \multicolumn{2}{|c|}{ significance } & \multicolumn{2}{|c|}{ LSD } \\
\hline N treatments & *** & $* * *$ & 0.38 \\
\hline Microbion UNC & n. s. & $* *$ & - \\
\hline $1^{\text {st }}, 2^{\text {nd }}$, and 3 ${ }^{\text {rd }}$ cuts & *** & $* * *$ & 0.44 \\
\hline
\end{tabular}

n. s.:not significant; **:significant at $\mathrm{P} \leq 1 \%$, ***: significant at $\mathrm{P} \leq 0.1 \%$

Biomass weights of grass in sandy soil were lower in all treatments and in all cuts than of chernozem soil, in spite of the fact that treatments were the same in both types of soils. That means that chernozem soil was more productive, namely the nutrient supply ability of chernozem soil was better than of sandy soil.

We measured the lowest biomass weights of ryegrass grown in two types of soils and in all cuts in control pots and the highest ones in pots with $\mathrm{N}_{3}$ doses.

It can be seen in Table 3. that the application of $\mathrm{N}_{1}$ dose significantly increased biomass weight of plants. In the $1^{\text {st }}$ and $2^{\text {nd }}$ cuts the biomass weight increased about fivefold in sandy soil and about twofold in chernozem soil compared to control values. Increasing effect of $\mathrm{N}_{1}$ dose became smaller in the last, $3^{\text {rd }}$ cut.

With increasing nitrogen supply $\left(\mathrm{N}_{2}\right.$ and $\mathrm{N}_{3}$ doses) the biomass production of grass significantly increased $(\mathrm{P}=0.1 \%)$ in both types of soils. In case of sandy soil the stimulating effect was more expressed, but values never reached the appropriate values of chernozem soil.

Comparing biomass weight values of $1^{\text {st }}, 2^{\text {nd }}$ and $3^{\text {rd }}$ cuts (in case of both soils) it can be seen, that in control pots and in pots with $\mathrm{N}_{1}$ treatment biomass weights decreased in the $2^{\text {nd }}$ cut compared to $1^{\text {st }}$ cut. On the contrary in pots with higher $\mathrm{N}$ dose, namely in $\mathrm{N}_{2}$ and $\mathrm{N}_{3}$ treatments, the biomass weights increased in $2^{\text {nd }}$ cut compared to values of $1^{\text {st }}$ cut. These contrary changes might be because of different $\mathrm{N}$ supply of soil. In the case of lower $\mathrm{N}$ supply the growth of grass took up higher amount of nitrogen in first cut, so less mineral nitrogen remained after that. In this case we measured highest biomass weights in the $1^{\text {st }}$ cut. In the case of higher $\mathrm{N}$ supply $\left(\mathrm{N}_{2}, \mathrm{~N}_{3}\right.$ doses) the growth of the cut did not use all mineral nitrogen, so higher amount of nitrogen remained for $2^{\text {nd }}$ cut's growth. In these pots we measured highest biomass weights in the $2^{\text {nd }}$ cuts.

Effect of biofertilizer application was not so expressed as the effect of $\mathrm{N}$ fertilizer. In the case of sandy soil we noticed slightly (but not significant) increased biomass weights in inoculated pots, and in the case of chernozem soil biofertilizer application caused significantly increased biomass weights of grass.

The effects of $\mathrm{NH}_{4} \mathrm{NO}_{3}$ and biofertilization on cumulated biomass weights of ryegrass cultivated on two types of soils are summarized in Figure 1. The results of statistical analysis are presented in Table 5. 
Figure 1.: Effects of increasing doses of $\mathrm{NH}_{4} \mathrm{NO}_{3}$ and Microbion $\mathrm{UNC}$ application on cumulated biomass weights of ryegrass grown on sandy and chernozem soils

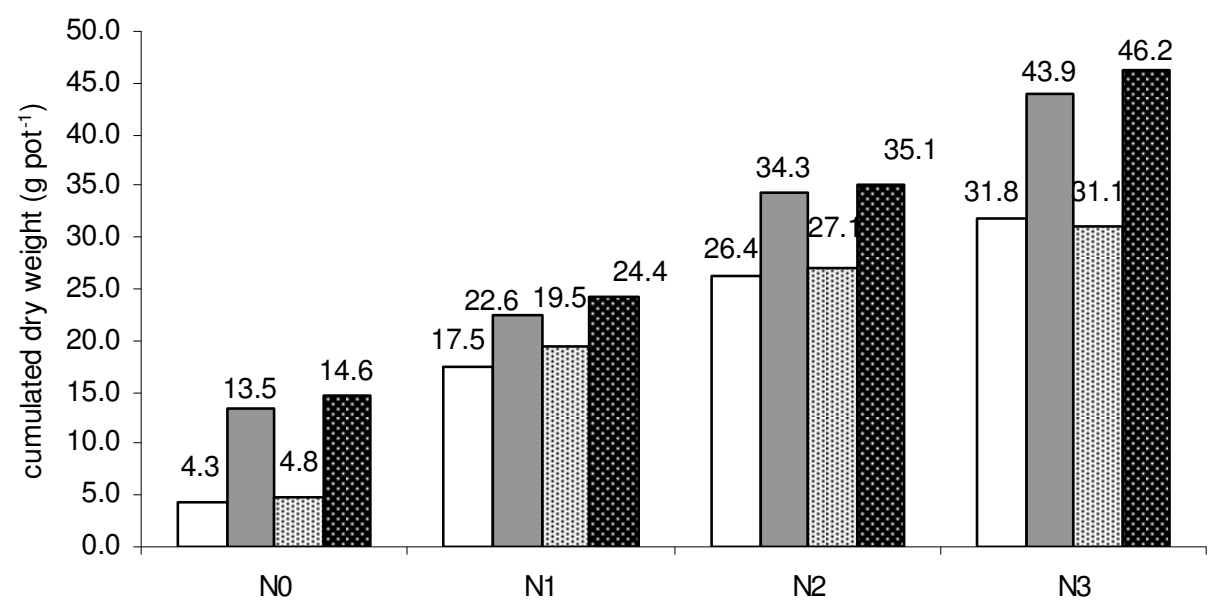

$\square$ sandy $\square$ chern. 固 sandy+Microbion UNC $\mathbf{g}$ chern.+Microbion UNC

Table 5.

Summary of ANOVA (F-test) for different source of variance

\begin{tabular}{|c|c|c|}
\hline & \multicolumn{2}{|c|}{ sandy soil } \\
\hline & sionificance & $L S D_{5 \%}$ \\
\hline $\mathrm{NH}_{4} \mathrm{NO}_{3}$ & $* * *$ & 1.32 \\
\hline MICROBION UNC & + & 0.93 \\
\hline & \multicolumn{2}{|c|}{ chernozem soil } \\
\hline $\mathrm{NH}_{4} \mathrm{NO}_{3}$ & $* * *$ & 1.20 \\
\hline MICROBION UNC & ** & 0.85 \\
\hline
\end{tabular}

+ significant at $\mathrm{P}<10 \%$; ** significant at $\mathrm{P}<1 \%$; *** significant at $\mathrm{P}<0.1 \%$

Cumulated dry weights of ryegrass grown on sandy soil also were lower and ranged between 4.31-31.81 g $\operatorname{pot}^{-1}$ and on chernozem soils were higher in the range of 13.51-46.23 $\mathrm{g} \mathrm{pot}^{-1}$.

The lowest values, as we experienced in $1^{\text {st }}, 2^{\text {nd }}$ and $3^{\text {rd }}$ cuts, we measured in control pots and the highest ones in pots with $\mathrm{N}_{3}$ treatment.

With increasing nitrogen supply the cumulated dry matter production of grass significantly increased $(\mathrm{P}=0.1 \%)$ in both types of soils but in case of sandy soil the increasing effect was more determined. The highest $\mathrm{NH}_{4} \mathrm{NO}_{3}$ doses caused a sevenfold increase of cumulated dry weights in sandy soil compared to the control value, and caused no more than a threefold increased values in chernozem soil.

These different changes on two types of soils were because of the difference of the original nutrient $\left(\mathrm{NO}_{3}{ }^{-}\right)$ content of soils. The original $\mathrm{NO}_{3}^{-}$content was lower in sandy soil that is why the effect of added nitrogen fertilizer on the dry weights was higher. Further increase of $\mathrm{NH}_{4} \mathrm{NO}_{3}$ doses yielded increased cumulated dry weights of ryegrass. The effect of $\mathrm{NH}_{4} \mathrm{NO}_{3}$ was significant at $\mathrm{P}<0.1 \%$.

Although application of bacterial fertilizer caused increased cumulated dry weights in both type of soils, the effect was more expressed on chernozem soil $(\mathrm{P}<1 \%$ level). We measured the highest cumulated dry weights in pots with $\mathrm{N}_{3}+$ Microbion UNC treatment.

\section{CONCLUSION}

The dry weights were higher in all pots in chernozem soil compared to sandy soil, in spite of the fact the treatments were the same in both type of soils. The chernozem soil had better nutrient supply ability than sandy soil.

With increasing nitrogen supply the dry matter production of grass increased significantly $(\mathrm{P}=0.1 \%)$ in both types of soils but in case of sandy soil the increasing effect was more pronounced. The highest $\mathrm{NH}_{4} \mathrm{NO}_{3}$ doses caused a sevenfold increase of cumulated dry weights in sandy soil compared to the control value, and caused no more than a threefold increase of dry weights in chernozem soil.

Application of Microbion UNC had positive effect on dry matter production of ryegrass grown on both types of soils, but the effect was more expressed in case of chernozem soil.

Finally it can be concluded that the increasing effect of $\mathrm{NH}_{4} \mathrm{NO}_{3}$ on dry weights was more expressed in both types of soils. The biofertilizer application also increased the dry weights of plant in a small degree in both of soils, but the level of significance was higher in chernozem soil. 


\section{REFERENCES}

Bambal, A.S.-R.M. Verma-D.M. Panchbhai-V.K. Mahorkar-R.N.Khankhane (1998): Effect of bio-fertilizers and nitrogen levels on growth and yield of cauliflower (Brassica oleracea var. botrytis). Orissa J. Hort., 26:14-7.

Black, C.A. (1968): Nitrogen. In Soil-Plant Rel., $2^{\text {nd }}$ ed.; Wiley: New York, 405-557.

Ghost, B.C.-Bhat, R. (1998): Environmental hazards of nitrogen loading in wetland rice fields. Environ. Pollut. 102, 123-126.

Hegde, D.M.-Dwived B.S.-Sudhakara, S.N. (1999): Biofertilizers for cereal production in India. Indian J. Agric. Sci. 69, $73-83$.

Jordan, T. E.-Weller, D. E. (1996): Human Contributions to Terrestrial Nitrogen Flux: Assessing the Sources and Fates of Anthropogenic Fixed Nitrogen, BioScience, 46. 665.

Kádár, I.-Márton, L.-Németh, T.-Szemes, I. (2007): Meszezés és mütrágyázás hatása a talajra és növényre a 44 éves nyírlugosi tartamkísérletben. Agrokémia és Talajtan, 56. 255-270.

Kátai, J.-Vágó, I.-Sándor, Zs-Tállai, M. (2008): The effect of an artificial and a bacterium fertilizer on some soil characteristics and on the biomass of the ryegrass (Lolium perenne L.). Cereal Research Communications Vol. 36. Suppl. 1171-1174.

Kincses I.-Filep T.-Kremper R..(2008): Effect of Nitrogen Fertilization and biofertilization on element content of parsley. Cereal Research Communic. 36. 571-574.

Malboobi, M. A.-Behbahani, M.-Madani, H.-Owlia, P.-Deljou, B.-Yakhchali, B.-Moradi, M.-Hassanabadi, H. (2009): Performance evaluation of potent phosphate solubilizing bacteria in potato rhizosphere. World Journal of Microbiology and Biotechnology 25. 14791484 .

Panwar, A.S.-J.S. Balyan-V.S. Verma (2000): Yield and quality of radish (Raphanus sativus) seed as affected by fertility levels and biofertilizers. Indian J. Agron., 45: 822-6.

Stevenson, F.J.-Cole, M. A. (1999): The nitrogen cycle in soil: Global and ecological aspects. In Cycles of Soil, 2nd ed.: Wiley: New York, 139-190.

Sipos M.-Vágó I. (2007): The effect of nitrogen supply, liming and nickel contamination on the productivity of ryegrass (Lolium perenne L.) in a greenhouse experiment. Joint International Conference on Long-term Experiments, Agricultural Research and Natural Resources. $1^{\text {st }}$ June. Debrecen-Nyírlugos. 163-169.

Vance, C.P. (1997): Enhanced agricultural sustainability through biological nitrogen fixation. In: Bio Fix of Nitrogen for Eco and Sustain Agric. Proc. NATO Adv Res. Work, Ponzan, Poland, 10-14 September 1996, Springer-Verlag, Berlin, Germany, 179-185.

Vessey J.K. (2003): Plant growth promoting rhizobacteria as biofertilizers. Plant Soil 255, 571-586. 